Research Article

\title{
Parameter Analysis on Hardening Soil Model of Soft Soil for Foundation Pits Based on Shear Rates in Shenzhen Bay, China
}

\author{
Yanbin Fu $\mathbb{D}^{1,2,3}$ Siyue He $\mathbb{D}^{2},{ }^{2}$ Sizhan Zhang $\mathbb{D},{ }^{1}$ and Yong Yang $\mathbb{D}^{4}$ \\ ${ }^{1}$ College of Civil and Transportation Engineering, Shenzhen University, Shenzhen, Guangdong 518060, China \\ ${ }^{2}$ Key Laboratory for Special Area Highway Engineering of Ministry of Education, Chang'an University, Xi'an, \\ Shaanxi 710064, China \\ ${ }^{3}$ Underground Polis Academy of Shenzhen University, Shenzhen, Guangdong 518060, China \\ ${ }^{4}$ JiZhunFangZhong Chengdu Architectural Design Co., Ltd., Chengdu, Sichuan 610000, China
}

Correspondence should be addressed to Siyue He; hesiyue@chd.edu.cn

Received 31 July 2019; Revised 15 December 2019; Accepted 16 December 2019; Published 18 February 2020

Academic Editor: Georgios I. Giannopoulos

Copyright (c) 2020 Yanbin Fu et al. This is an open access article distributed under the Creative Commons Attribution License, which permits unrestricted use, distribution, and reproduction in any medium, provided the original work is properly cited.

\begin{abstract}
The hardening soil (HS) model is the most commonly used constitutive models of soft soil of foundation pits of PLAXIS software in numerical analysis, and its parameters are prerequisite for accurate calculation. In this paper, relevant parameters of the HS model in Shenzhen Bay in China were studied through one-dimensional consolidation tests and triaxial shear tests. Analytical methods of reference secant stiffness and failure ratio of soft soil were systematically studied, the influence of shear rates on reference secant stiffness and failure ratio of soft soil was analyzed, and the relationship between stiffness parameters and compressive modulus of soft soil was established. The results showed that reference secant stiffness and failure ratio of soft soil obtained by different analytical methods were quite different, and the errors of reference secant stiffness and failure ratio of soft soil obtained by stress-strain curves were the smallest and the stability was the best; at the same time, with increase of shear rates, the peak deviator stress and reference secant stiffness of soft soil increased, but failure ratio did not change much. The research results could provide a reference of parameter analysis of soft soil for the HS model in the numerical analysis and similar working conditions of foundation pits.
\end{abstract}

\section{Introduction}

With rapid development of economy, more and more foundation pits adjacent to metro tunnels, metro stations, buildings, and municipal pipelines have been built in soft soil in coastal areas. Excavation of foundation pits has great impact on these adjacent projects and even causes surface collapse. It is difficult to analyze the influence of excavation of foundation pits on surrounding environment in soft soil reasonably by traditional analytical methods and relevant normative methods $[1,2]$. The numerical analysis method has become the most effective method for excavation of foundation pits in soft soil because it can take into account the stratification and nature of soil, distribution and nature of support systems, construction process of excavation and support structures, and influence on surrounding environment [7-10].
The key point in numerical simulation is to adopt reasonable calculation parameters and constitutive models. The Mohr-Coulomb (MC) model, Duncan-Chang (DC) model, Drucker-Prager (DP) model, modified Cam-Clay (CC) model, cap model, and hardening soil (HS) model are commonly used in numerical simulation of excavation of foundation pits in soft soil [7-8]. The applicable conditions for different constitutive models of cemented clay and soft soil are shown in Table 1 . The MC model is usually used in the rapid analysis of numerical simulation. When soft soil has shear-softening effect, yield surface with cap shape is suitable, such as DP model, modified CC model, and cap model [11-13], among which, the HS model can consider hardening characteristics of soft soil and distinguish the difference between loading and unloading, and its stiffness parameters depend on stress history and stress path; its 
Table 1: The applicable conditions for different constitutive models of cemented clay and soft soil.

\begin{tabular}{|c|c|c|c|c|c|c|c|}
\hline \multirow{2}{*}{ Constitutive models } & \multirow{2}{*}{ Analysis type } & \multicolumn{3}{|c|}{ Soft soil } & \multicolumn{3}{|c|}{ Cemented clay } \\
\hline & & OCR $>1$ & $\mathrm{OCR} \approx 1$ & OCR $<1$ & Sandy soil & Low compressibility & High compressibility \\
\hline MC model & $\begin{array}{l}\text { Serviceability limit state } \\
\text { Bearing capacity limit state }\end{array}$ & + & & & ++ & + & \\
\hline & Serviceability limit state & + & & & ++ & ++ & + \\
\hline DC model & Bearing capacity limit state & + & & & ++ & ++ & + \\
\hline DP model & Serviceability limit state & ++ & + & + & ++ & ++ & ++ \\
\hline DP model & Bearing capacity limit state & ++ & + & + & ++ & ++ & ++ \\
\hline Modified CC model & $\begin{array}{c}\text { Serviceability limit state } \\
\text { Bearing capacity limit state }\end{array}$ & & $\begin{array}{c}+ \\
++\end{array}$ & $\begin{array}{c}+ \\
++\end{array}$ & & & $\begin{array}{c}+ \\
++\end{array}$ \\
\hline Cap model & $\begin{array}{l}\text { Serviceability limit state } \\
\text { Bearing capacity limit state }\end{array}$ & $\begin{array}{c}+ \\
++\end{array}$ & $\begin{array}{l}++ \\
++\end{array}$ & $\begin{array}{l}++ \\
++\end{array}$ & $\begin{array}{c}+ \\
++\end{array}$ & $\begin{array}{c}+ \\
++\end{array}$ & $\begin{array}{c}+ \\
++\end{array}$ \\
\hline HS model & $\begin{array}{c}\text { Serviceability limit state } \\
\text { Bearing capacity limit state }\end{array}$ & $\begin{array}{l}+++ \\
+++\end{array}$ & $\begin{array}{l}++ \\
++\end{array}$ & $\begin{array}{l}++ \\
++\end{array}$ & $\begin{array}{l}++ \\
+++\end{array}$ & $\begin{array}{l}++ \\
+++\end{array}$ & $\begin{array}{l}++ \\
+++\end{array}$ \\
\hline
\end{tabular}

OCR: over consolidation ratio; +: generally applicable, the effect is not ideal; ++: applicable, good effect; +++: applicable, very good effect.

calculation results can give reasonable wall deformation and soil deformation behind wall at the same time, which is suitable for numerical analysis of excavation of foundation pits in soft soil [14-16]. Therefore, the HS model has become one of the most widely used constitutive models in the numerical analysis of excavation of foundation pits in soft soil. However, the HS model has many parameters, and it is difficult to obtain more complete model parameters $[17,18]$.

At present, the main methods to determine parameters of HS model are the back-analysis method based on measured data and the laboratory test method $[19,20]$. The backanalysis method can obtain sensitive parameters, and determination of other parameters depends on engineering experience; because of complexity of foundation pits, it is sometimes difficult for measured data to truly reflect actual state of projects $[21,22]$. The laboratory test method can directly test the physical and mechanical properties of soft soil, and it is an effective method to obtain the parameters $[23,24]$. Up to now, some studies have obtained some parameters of the HS model through the laboratory test, and only a few have obtained relatively complete parameters of the HS model $[2,15,25,26]$. In this paper, the parameters of the HS model of soft soil in Shenzhen Bay in China were obtained through one-dimensional consolidation tests and triaxial shear tests. Based on theory of nonlinear elastic deformation of soft soil, analytical methods of reference secant stiffness and failure ratio in parameters of the HS model were systematically studied, and influence of shear rates on parameters of HS model was summarized.

\section{HS Model}

The HS model is a constitutive model based on Vermeer's double hardening soil model proposed by Schanz and Vermeer [27, 28]. It consists of a hyperbolic shear yield surface and an elliptic cap yield surface in the P-Q plane, as shown in Figure 1(a). It model can consider both shear hardening and compression hardening of soft soil and satisfy Mohr-Coulomb failure criterion. It is suitable for simulating different types of soft soil in foundation pits. This model contains 11 parameters; it can be divided into three categories: strength parameter, stiffness parameter, and advanced parameter $[29,30]$, as shown in Table 2 . In this paper, effective cohesion, effective friction angle, reference tangent stiffness, reference secant stiffness, reference unloading/ reloading stiffness, failure ratio, and other parameters were studied. These parameters could be obtained from onedimensional consolidation tests and triaxial shear tests. Stress-strain curves were very important in parameter analysis of the HS model [31-33], and typical stress-strain curves of triaxial shear tests are shown in Figure 1(b).

\section{Materials and Methods}

3.1. Materials. To obtain more accurate parameters of the HS model, one-dimensional consolidation tests and triaxial shear tests were carried out of soft soil in Shenzhen Bay in China. The physical parameters of soil samples are shown in Table 3.

\subsection{Methods}

3.2.1. One-Dimensional Consolidation Tests. In this test, the compression characteristics of soft soil in Shenzhen Bay were studied by using the WG lever consolidation equipment. Consolidation tests of T1, T2, and T3 soil samples were carried out, respectively. Height $(H)$ of soil samples was $2 \mathrm{~cm}$, and section area $(S)$ was $30 \mathrm{~cm}^{2}$. During one-dimensional consolidation tests, soil samples were placed in rigid retaining ring, and only vertical deformation occurred under lateral restriction of retaining ring and the ring knife, so as to achieve the purpose of one-dimensional compression.

3.2.2. Triaxial Shear Tests. The test equipment was a fully automatic and high-precision triaxial apparatus from GDS Company, UK. Height $(H)$ of soil samples was $7.6 \mathrm{~cm}$, and diameter $(D)$ was $3.9 \mathrm{~cm}$. In this section, triaxial shear tests at the same shear rate and at different shear rates were carried out, respectively. Sample preparation and installation process in triaxial shear tests is shown in Figure 2. At the same 


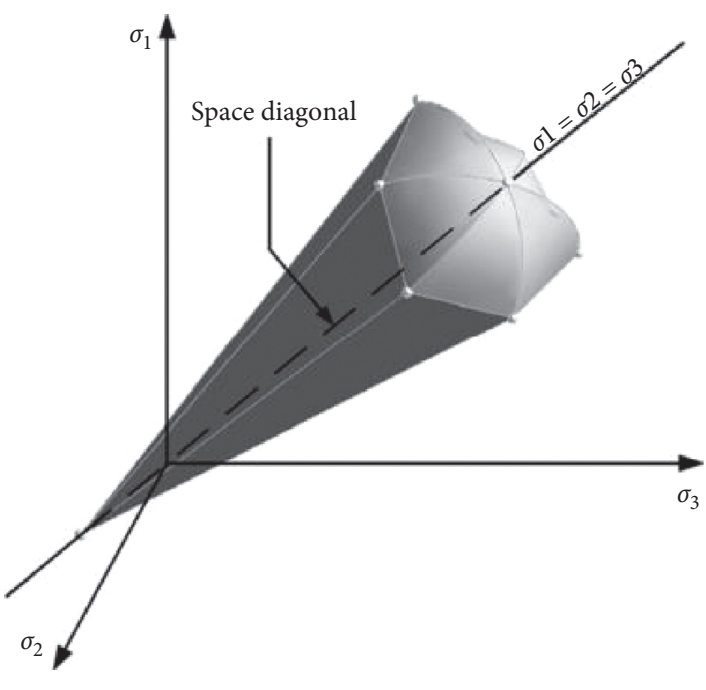

(a)

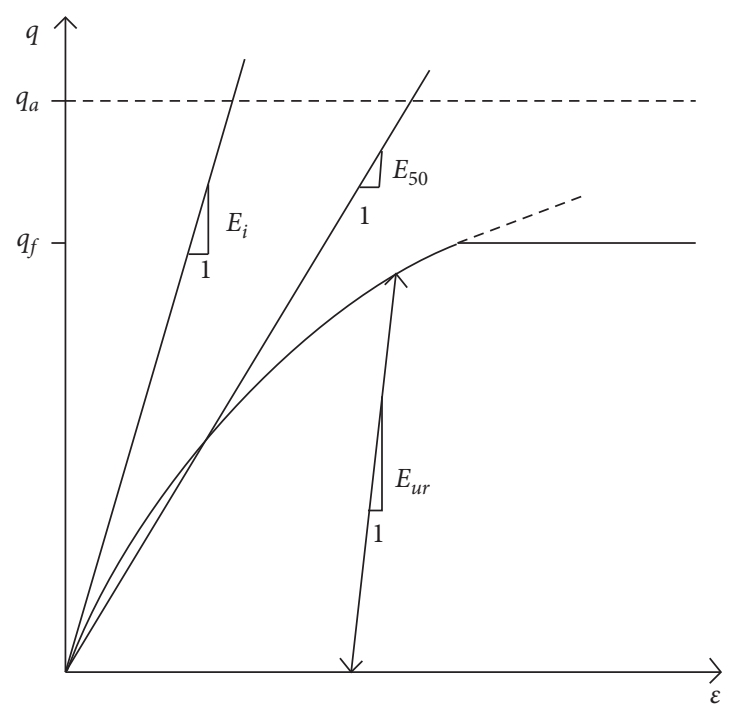

(b)

Figure 1: (a) Yield surface in the P-Q plane and (b) stress-strain curves of the HS model.

TABLE 2: Main parameters of the HS model $[29,30]$.

\begin{tabular}{lcc}
\hline Strength parameter & Stiffness parameter & Advanced parameter \\
\hline Effective cohesion $c^{\prime}$ & Reference secant stiffness $E_{50}^{\text {ref }}$ & Reference stiffness stress $p^{\text {ref }}$ \\
Effective friction angle $\varphi^{\prime}$ & Reference tangent stiffness $E_{\text {oed }}^{\text {ref }}$ & Unloading/reloading Poisson's ratio $v_{\text {ur }}$ \\
Dilation angle $\psi$ & Side pressure coefficient $K_{0}$ & Reference unloading/reloading stiffness $E_{\text {ur }}^{\text {ref }}$ \\
- & Failure ratio $R_{f}$ & Power exponent of stiffness-stress level correlation $m$ \\
\hline
\end{tabular}

Table 3: Physical parameters of soil samples.

\begin{tabular}{|c|c|c|c|c|c|}
\hline Soil samples & Depth $(\mathrm{m})$ & Water content $(\%)$ & Density $\left(\mathrm{g} \cdot \mathrm{cm}^{-3}\right)$ & Specific gravity & Void ratio \\
\hline $\mathrm{T} 1$ & $2.2 \sim 3.4$ & 48.3 & 1.67 & 2.70 & 1.40 \\
\hline $\mathrm{T} 2$ & $4.0 \sim 5.5$ & 47.5 & 1.74 & 2.71 & 1.31 \\
\hline $\mathrm{T} 3$ & $6.5 \sim 7.8$ & 48.4 & 1.64 & 2.69 & 1.42 \\
\hline
\end{tabular}

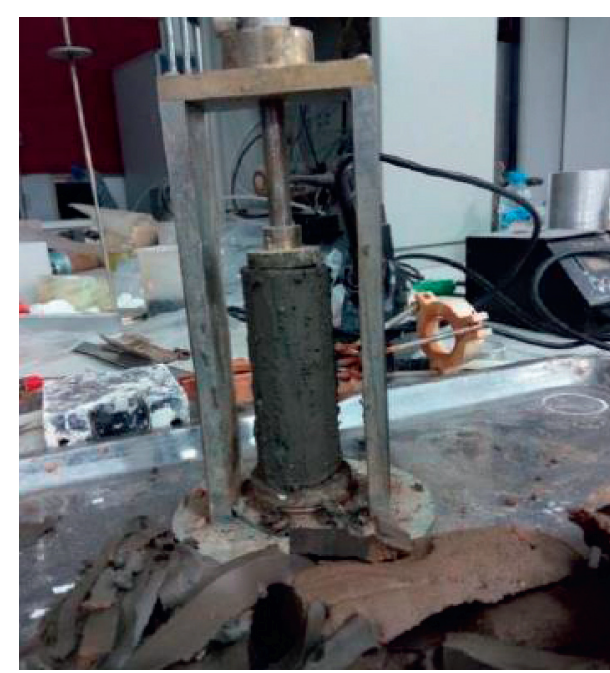

(a)

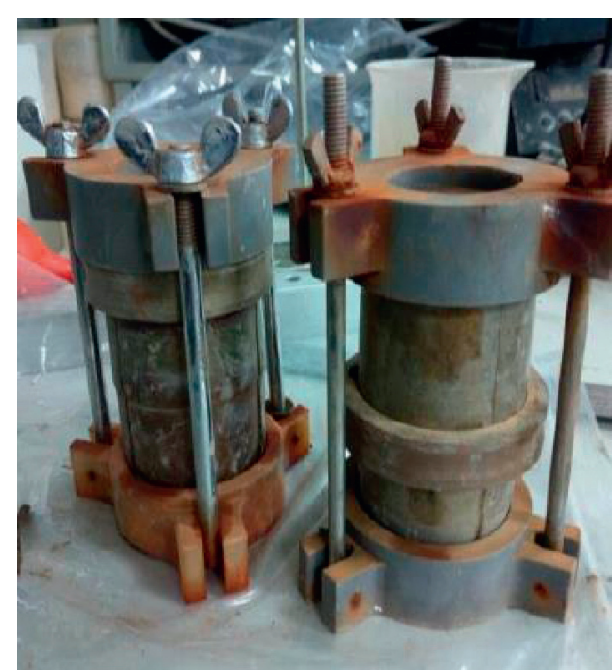

(b)

Figure 2: Continued. 


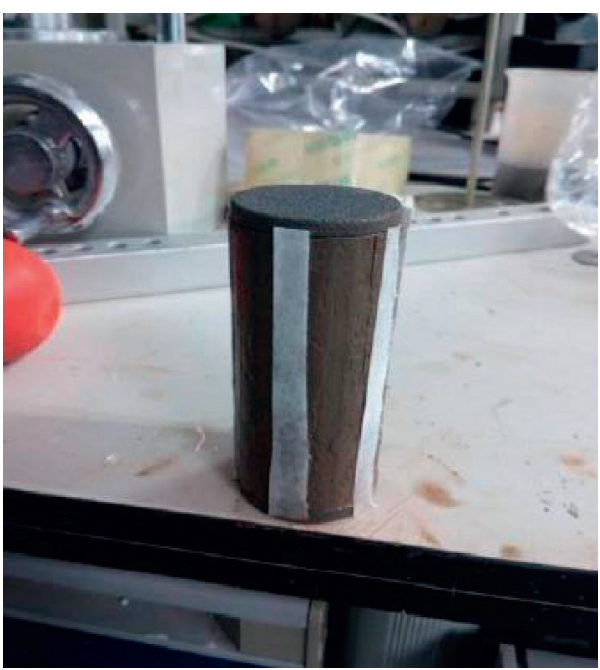

(c)

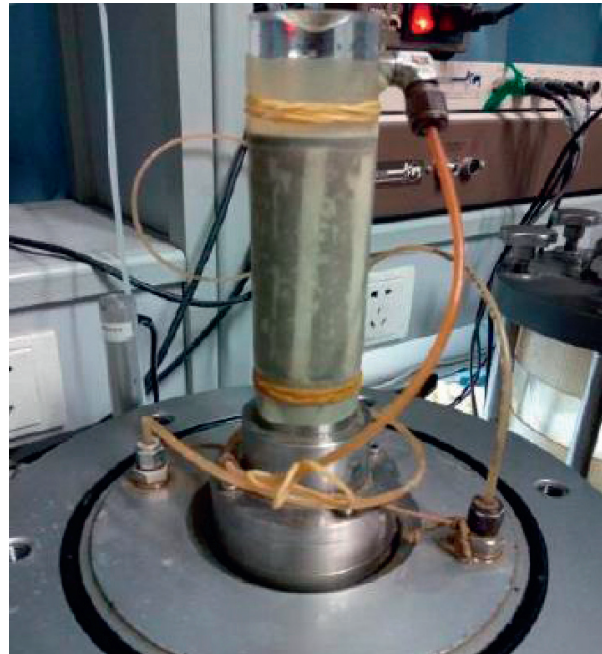

(d)

FIGURE 2: Sample preparation and installation process in triaxial shear tests. (a) Sample preparation. (b) Sample saturator. (c) Sample pasted with filter paper. (d) Sample installation.

shear rate, through consolidated drainage shear $(\mathrm{CD})$ tests on T1, T2, and T3 soil samples, effective stress intensity index, reference secant stiffness, and failure ratio of soft soil in Shenzhen Bay were determined under reference stiffness stress $p^{\text {ref }}=100 \mathrm{kPa}$. The shear rate was set to $V=0.002 \mathrm{~mm} /$ min and confining pressure was $100 \mathrm{kPa}$; the shear rate could reduce the influence of pore water pressure on strength and prevent excess pore water pressure [34]. At different shear rates, consolidated undrained shear (CU) tests were carried out on the T1 soil sample to study the shear properties of soft soil in Shenzhen Bay. To obtain reference secant stiffness and failure ratio of soft soil at different shear rates, shear rates were set to $0.05 \mathrm{~mm} / \mathrm{min}$ and $0.15 \mathrm{~mm} / \mathrm{min}$ and the shear rates could be controlled to ensure that the pore water pressure increases uniformly and conforms to the actual engineering [32].

\section{Results and Analysis}

4.1. Analysis of Reference Tangent Stiffness. Results of onedimensional consolidation tests and fitting curves of soil samples are shown in Figures 3 and 4 . Figure 3 shows the relationship between axial load $(p)$ and void ratio $(e)$ of soil samples. Figure 4 shows the relationship between axial strain $\left(\varepsilon_{1}\right)$ of soil samples and axial load $(p)$.

As can be seen from Figure 3, the larger axial load $(p)$ on soil samples is, the smaller void ratio $(e)$ of soil samples is, and the smaller void ratio of soil samples after consolidation and compression is. The compressive modulus $\left(E_{s, 1-2}\right)$ of soil samples was $2.26 \mathrm{MPa}, 2.34 \mathrm{MPa}$, and $2.16 \mathrm{MPa}$, respectively, when the axial load was as follows: $p_{1}=100 \mathrm{kPa}$ to $p_{2}=200 \mathrm{kPa}$.

As can be seen from Figure 4, the axial strain $\left(\varepsilon_{1}\right)$ of soil samples increased with increase in the axial load $(p)$ on soil samples. After derivation calculation, reference tangent stiffness
$\left(E_{\text {oed }}^{\text {ref }}\right)$ of soil samples were $1.99 \mathrm{MPa}, 2.09 \mathrm{MPa}$, and 2.06 MPa, with an average value of $2.05 \mathrm{MPa}$.

4.2. Analysis of Strength Parameter. In this paper, the strength parameter was determined according to the relationship between Mohr-Coulomb strength envelope and $K_{f}^{\prime}$ line [2]. The results of CD tests and fitting curves of soil samples are shown in Figure 5:

$$
\begin{aligned}
& \varphi^{\prime}=\arcsin \left(\tan \alpha^{\prime}\right), \\
& c^{\prime}=\frac{a^{\prime}}{\cos \varphi^{\prime}},
\end{aligned}
$$

where $\tan \alpha^{\prime}$ is the slope of fitting line and $a^{\prime}$ is the intercept.

Effective friction angle $\left(\varphi^{\prime}\right)$ of T1, T2, and T3 soil samples was $21.5^{\circ}, 21.3^{\circ}$, and $21.3^{\circ}$, respectively, and the average value was $21.4^{\circ}$; effective cohesion $\left(c^{\prime}\right)$ of $\mathrm{T} 1, \mathrm{~T} 2$, and $\mathrm{T} 3$ soil samples was $7.1 \mathrm{kPa}, 6.7 \mathrm{kPa}$, and $7.3 \mathrm{kPa}$, respectively, and the average value was $7.0 \mathrm{kPa}$.

\subsection{Analysis of Reference Secant Stiffness and Failure Ratio}

4.3.1. Reference Secant Stiffness and Failure Ratio at the Same Shear Rate. CD tests were carried out on soil samples. Effective confining pressure was $100 \mathrm{kPa}$. Three methods were proposed to analyze the reference secant stiffness $\left(E_{50}^{\text {ref }}\right)$ and failure ratio $\left(R_{f}\right)$.

(1) Analyzing by the relation of $\varepsilon_{1} \sim q$ : according to Kondner et al. [35], $\varepsilon_{1} \sim q$ curves of soil samples were fitted in the form of hyperbolic equation as follows:

$$
q=\sigma_{1}-\sigma_{3}=\frac{\varepsilon_{1}}{a+b \varepsilon_{1}}
$$




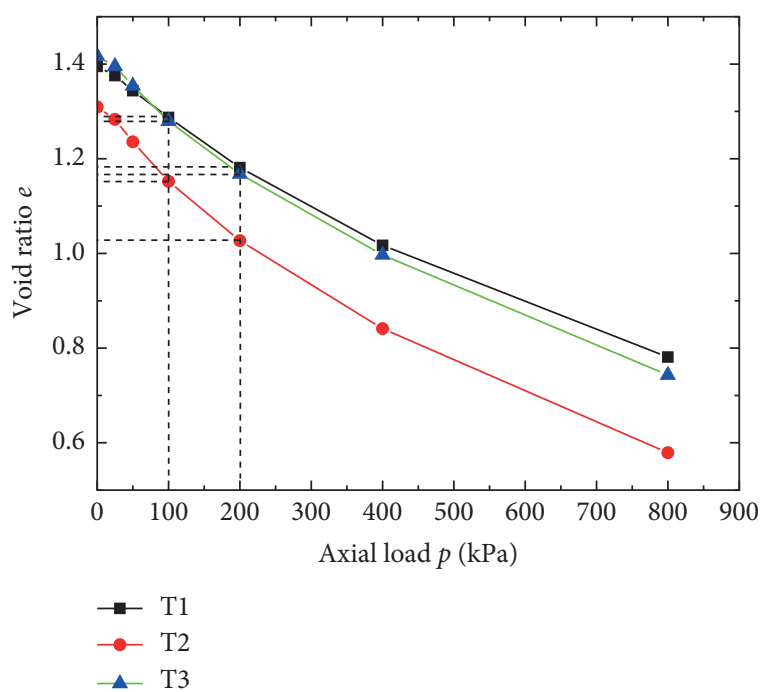

Figure 3: Axial load and void ratio curves of one-dimensional consolidation tests $(p \sim e)$.

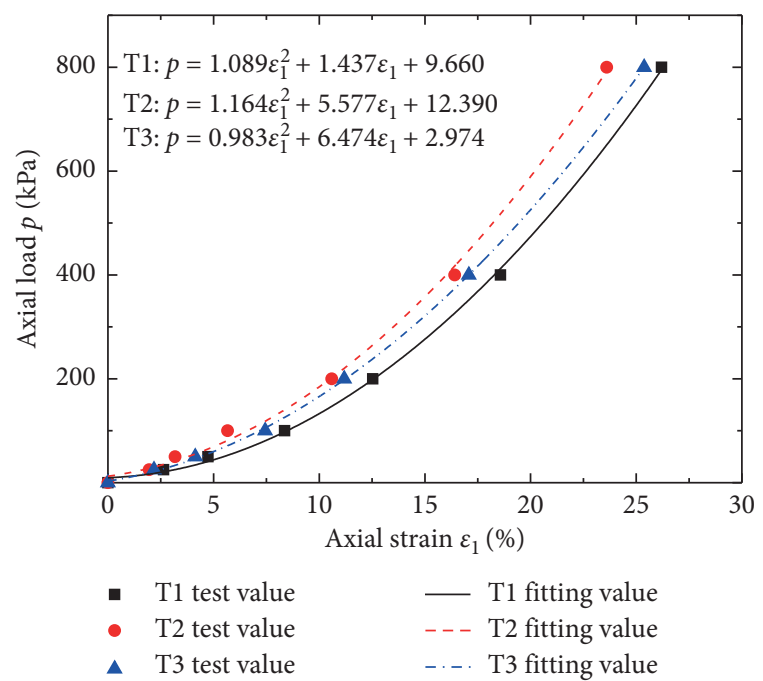

FIgURE 4: Axial strain and axial load curves of one-dimensional consolidation tests $\left(\varepsilon_{1} \sim p\right)$.

$\varepsilon_{1} \sim q$ curves and fitting curves of soil samples are shown in Figure 6.

Because there is no yield point in $\varepsilon_{1} \sim q$ curves of soil samples, combined with guideline of geotechnical test method [34], failure stress $\left(q_{f}\right)$ is deviator stress corresponding to strain $\varepsilon_{1}=15 \%$. Reference secant stiffness $\left(E_{50}^{\text {ref }}\right)$ was the slope of a straight line connecting the origin and the corresponding point $\left(0.5 q_{f}\right)$. The failure ratio $\left(R_{f}\right)$ of soil samples could be obtained from the following equation:

$$
R_{f}=\frac{q_{f}}{q_{a}},
$$

where $q_{a}$ is the asymptotic value of deviator stress of soil samples, which could be obtained by fitting the hyperbolic equation.

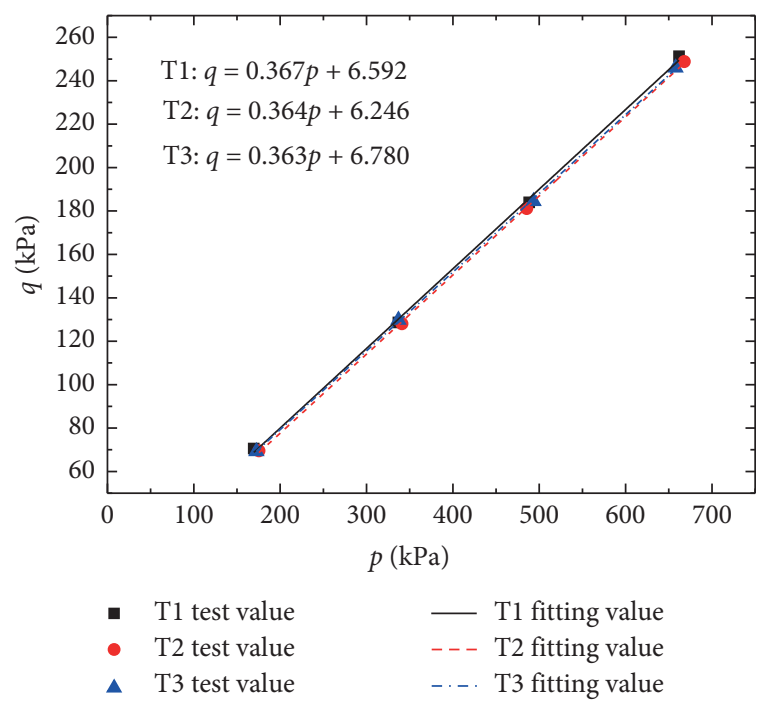

FIgURE 5: Results of CD tests and fitting curves of soil samples $(p \sim q)$.

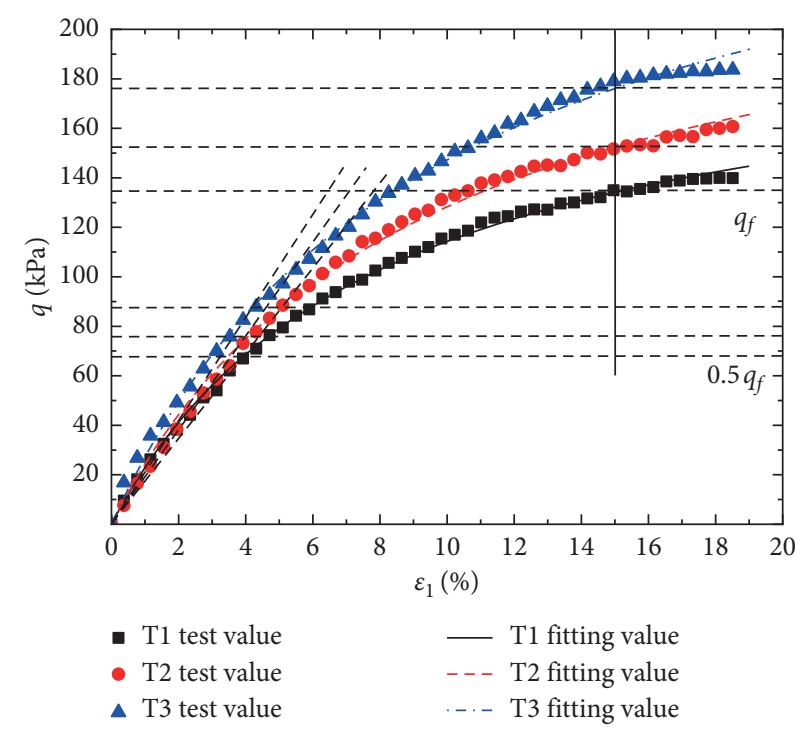

FIGURE 6: $\varepsilon_{1} \sim q$ curves of CD tests.

(2) Analyzing by relation of $1 / \varepsilon_{1} \sim 1 / q$ : according to Kondner [35], the relationship between the axial strain and deviator stress of soil samples was approximately a hyperbola, which could be expressed as follows:

$$
\varepsilon_{1}=\frac{1}{E_{i}} \frac{q}{1-q / q_{a}}, \quad q<q_{f},
$$

where $E_{i}$ is the initial stiffness, $q_{a}$ is the asymptotic value of deviator stress, and $q_{f}$ is the ultimate deviator stress.

By transforming equation (4), the $1 / \varepsilon_{1} \sim 1 / q$ correlation can be obtained as follows:

$$
\frac{1}{q}=\frac{1}{E_{i}} \frac{1}{\varepsilon_{1}}+\frac{1}{q_{a}},
$$


where data $1 / \varepsilon_{1}$ and $1 / q$ could be obtained by transforming experimental data. The correlation between them is shown in Figure 7. The relationship between $E_{i}$ and $E_{50}$ is as follows:

$$
E_{i}=\frac{2 E_{50}}{2-R_{f}}
$$

(3) Analyzing by relation of $\varepsilon_{1} \sim \varepsilon_{1} / q$ : according to Schanz et al. [22, 27], the yield curves of soil samples of $\mathrm{CD}$ tests could be expressed as follows:

$$
\varepsilon_{1}=\frac{q_{a}}{2 E_{50}} \frac{\sigma_{1}-\sigma_{3}}{q_{a}-\left(\sigma_{1}-\sigma_{3}\right)}, \quad q<q_{f} .
$$

Because $q=\sigma_{1}-\sigma_{3}$, equation (7) can be transformed into the following equation:

$$
\varepsilon_{1}=\frac{q}{2 E_{50}\left(1-q / q_{a}\right)} .
$$

Further conversion of equation (8) led the $\varepsilon_{1} \sim \varepsilon_{1} / q$ relationship as follows:

$$
\frac{\varepsilon_{1}}{q}=\frac{\varepsilon_{1}}{q_{a}}+\frac{1}{2 E_{50}}, \quad q<q_{f} .
$$

The ratio of actual deviator stress to ultimate deviator stress was defined as stress level and expressed as

$$
S_{1}=\frac{q}{q_{f}}
$$

According to the Mohr-Coulomb failure criterion, there were following relations:

$$
q_{f}=\left(\sigma_{1}-\sigma_{3}\right)_{f}=\frac{2 \sigma_{3} \sin \varphi+2 \cos \varphi}{1-\sin \varphi} .
$$

Through linear fitting of $\varepsilon_{1} \sim \varepsilon_{1} / q$ curves, parameters $q_{a}, E_{50}$ could be obtained. To avoid excessive error of linear fitting, two points of stress levels $S_{1}=70 \%$ and $S_{1}=95 \%$ were selected to fit on the basis of the DC model. $\varepsilon_{1} \sim \varepsilon_{1} / q$ curves are shown in Figure 8.

$E_{50}^{\text {ref }}$ and $R_{f}$ were obtained by using above three methods, and results are shown in Figure 9.

From Figure 9(a), it can be seen that the failure ratio $\left(R_{f}\right)$ difference obtained by using $\varepsilon_{1} \sim q$ curves was the smallest and the stability was the best, and $R_{f}$ difference obtained by using $1 / \varepsilon_{1} \sim 1 / q$ curves was the greatest, and difference between the minimum and the maximum was 0.48 , reaching $52.7 \%$. For the same soil samples, the lowest difference of $R_{f}$ was T1 and the biggest difference of $R_{f}$ was T3. Among them, the largest difference of $R_{f}$ was obtained by using $1 / \varepsilon_{1} \sim 1 / q$ curves, reaching 0.91 .

From Figure 9(b), it can be seen that the difference of reference secant stiffness $\left(E_{50}^{\text {ref }}\right.$ ) between $\varepsilon_{1} \sim q$ curves and $\varepsilon_{1} \sim \varepsilon_{1} / q$ curves was small, $1 / \varepsilon_{1} \sim 1 / q$ curves were the biggest, and difference between minimum and maximum was $0.78 \mathrm{MPa}$, reaching $32.0 \%$. For the same soil samples, the smallest difference of $E_{50}^{\text {ref }}$ was $\mathrm{T} 1$ and the biggest difference of $E_{50}^{\text {ref }}$ was T3. The largest difference of $E_{50}^{\text {ref }}$ obtained by

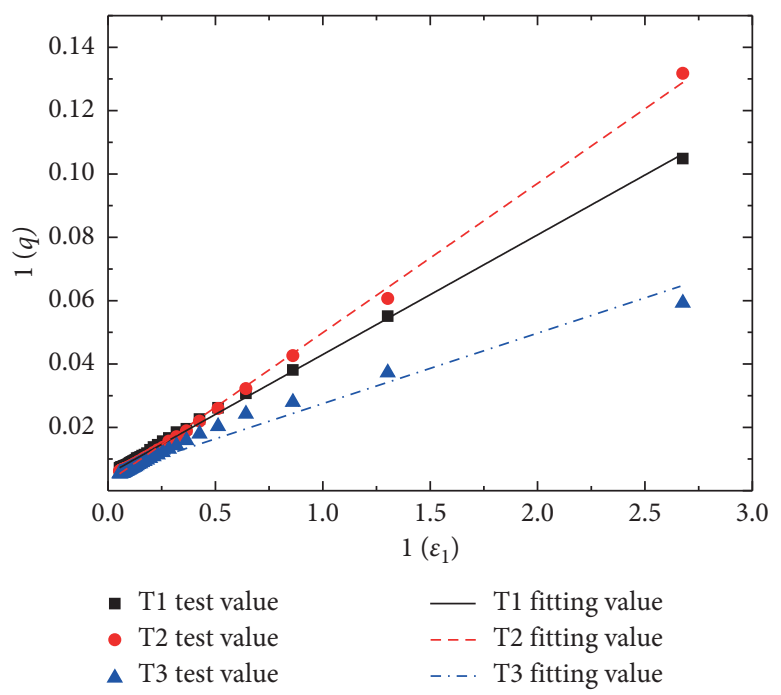

Figure $7: 1 / \varepsilon_{1} \sim 1 / q$ relation curves.

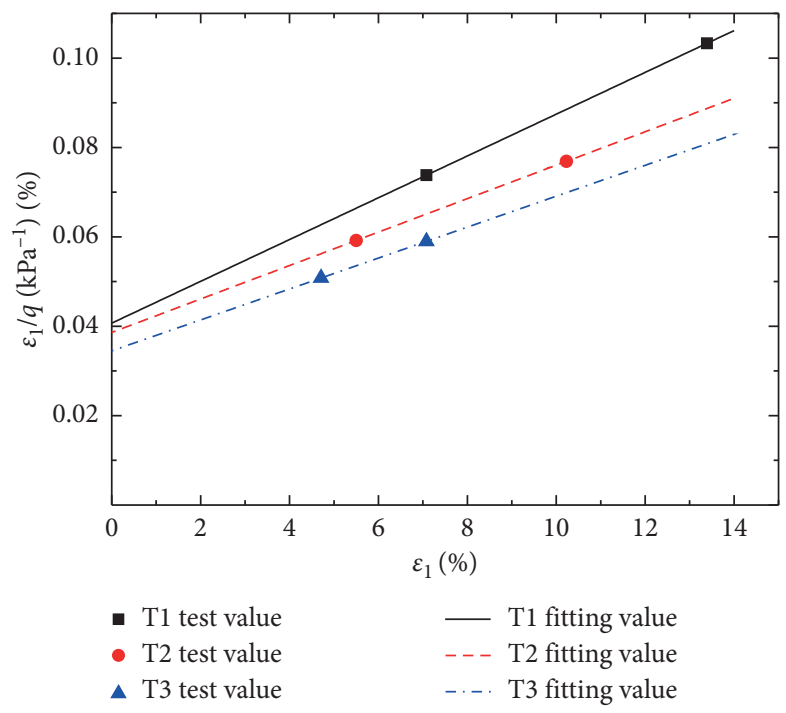

FIGURE 8: $\varepsilon_{1} \sim \varepsilon_{1} / q$ curves.

$1 / \varepsilon_{1} \sim 1 / q$ curves was $2.44 \mathrm{MPa}$, which was $0.99 \mathrm{MPa}$ larger than the minimum.

Based on the above analysis, the following conclusions could be drawn: failure ratio $\left(R_{f}\right)$ and reference secant stiffness $\left(E_{50}^{\text {ref }}\right)$ obtained by using $\varepsilon_{1} \sim q$ curves were less error and more stable, which were more suitable for parameter analysis of the HS model. Therefore, to reduce the error, the reference secant stiffness $\left(E_{50}^{\text {ref }}\right)$ in CU tests at different shear rates was solved by $\varepsilon_{1} \sim q$ curves, and the stiffness relationship was mainly based on $\varepsilon_{1} \sim q$ curves.

4.3.2. Reference Secant Modulus at Different Shear Rates. When effective confining pressure of soil samples was $100 \mathrm{kPa}$, shear rates and stress-strain curves in CU tests are shown in Figure 10.

From Figure 10, it can be seen that peak deviator stress increased to some extent with increase of shear rates in a 


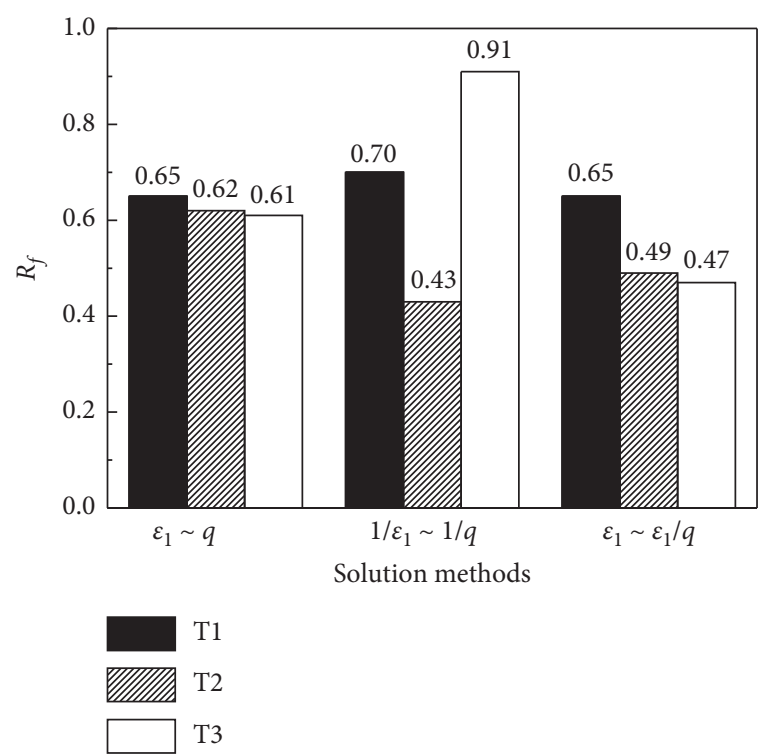

(a)

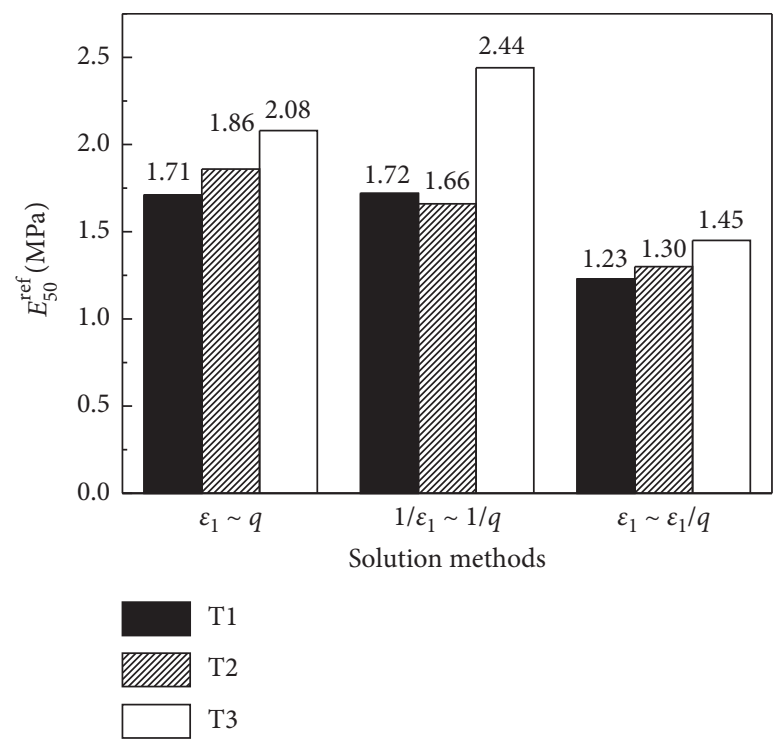

(b)

FIgURE 9: $R_{f}$ and $E_{50}^{\text {ref }}$ obtained by using the above three methods. (a) $R_{f}$ contrast. (b) $E_{50}^{\text {ref }}$ contrast.

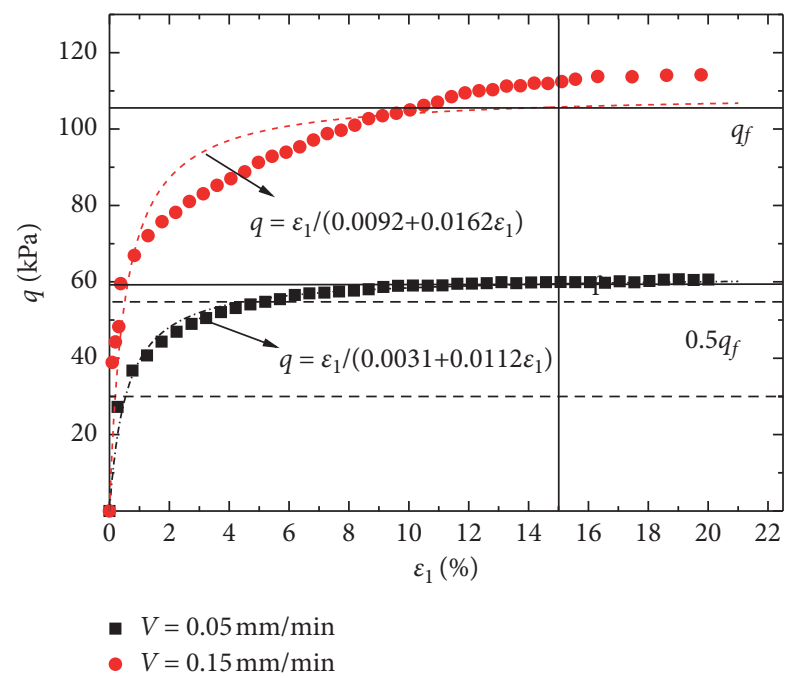

Figure 10: $\varepsilon_{1} \sim q$ curve based on different shear rates in CU tests.

certain range. Compared with stress-strain curves obtained from CD tests, stress-strain curves obtained from CU tests tended to enter "hardening" stage ahead of time. According to fitting hyperbola, reference secant stiffness $\left(E_{50}^{\text {ref }}\right)$ and failure ratio $\left(R_{f}\right)$ of the HS model were obtained, as shown in Table 4 . It could be seen that, within a certain range of shear rates, with increase of shear rates, shear strength failure value $\left(q_{f}\right)$, shear strength progressive value $\left(q_{a}\right)$, and reference secant stiffness $\left(E_{50}^{\text {ref }}\right)$ also increased gradually, and the failure ratio $\left(R_{f}\right)$ changed little with shear rates and was close to 1 .

4.4. Analysis of Unloading and Reloading Reference Secant Moduli. Figure 11 shows the stress-strain curves of soil samples under loading-unloading-reloading under CD tests of effective confining pressure $=100 \mathrm{kPa}$.
It can be seen that the stress-strain relationship has hysteresis loops, and the curve of unloading stage decreased rapidly. When unloading to a deviator stress, the curve of the unloading stage decreased slowly. When the unloading stage completed, the curve rose quickly and then slowly. Reference unloading/reloading stiffness $\left(E_{\mathrm{ur}}^{\mathrm{ref}}\right)$ of soil samples was the slope of line connecting the two ends of hysteresis loops. $E_{\text {ur }}^{\mathrm{ref}}$ of the soil samples was $11.76 \mathrm{MPa}, 13.03 \mathrm{MPa}$, and 15.12 $\mathrm{MPa}$, respectively.

\section{Discussion}

Compared with other constitutive models, the HS model can well describe the mechanical behavior of shear hardening of soil samples, but in practical engineering, there were many parameters and it was difficult to determine. By analyzing 
TABLE 4: Analytical results of partial parameters based on different shear rates in CU tests.

\begin{tabular}{lccccrr}
\hline Soil sample & Shear rates $(\mathrm{mm} / \mathrm{min})$ & $q_{f}(\mathrm{kPa})$ & $0.5 q_{f}(\mathrm{kPa})$ & $q_{a}(\mathrm{kPa})$ & $E_{50}^{\mathrm{ref}}(\mathrm{MPa})$ & $R_{f}$ \\
\hline \multirow{2}{*}{$\mathrm{T} 1$} & 0.05 & 59.5 & 29.8 & 61.7 & 5.61 & 0.96 \\
& 0.15 & 107.8 & 54.0 & 113.6 & 7.40 & 0.95 \\
\hline
\end{tabular}

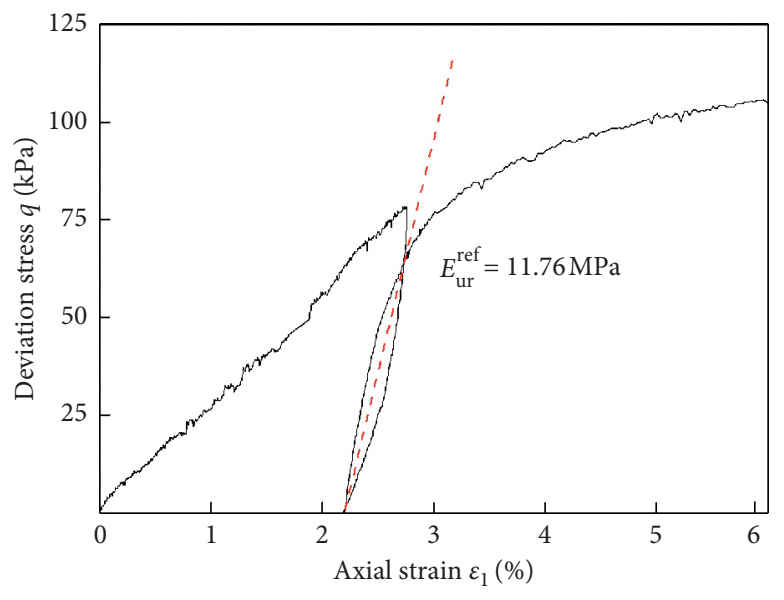

(a)

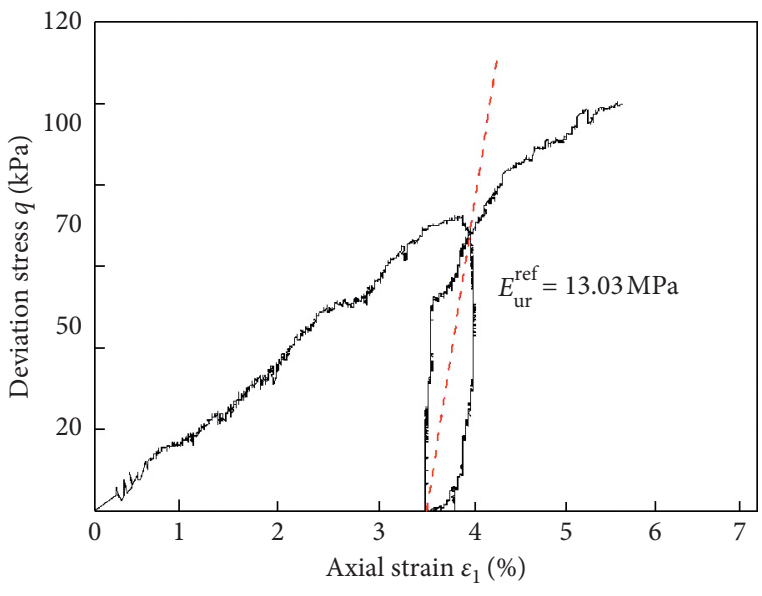

(b)

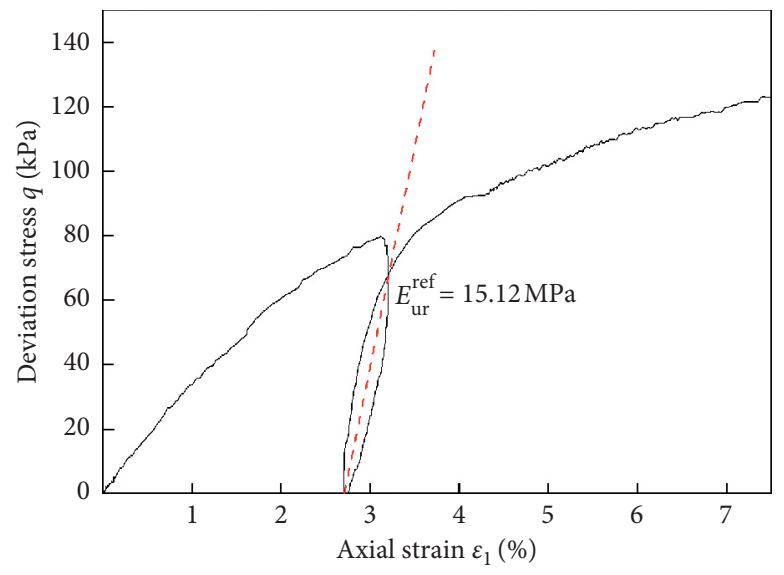

(c)

FIGURE 11: $\varepsilon \sim q$ curves under loading-unloading-reloading under CD tests. (a) T1. (b) T2.

TABLE 5: Relationship of stiffness parameters of soil samples.

\begin{tabular}{|c|c|c|c|c|c|}
\hline Soil sample & $E_{s 1-2}(\mathrm{MPa})$ & $E_{\text {oed }}^{\text {ref }}(\mathrm{MPa})$ & $E_{50}^{\mathrm{ref}}(\mathrm{MPa})$ & $E_{\text {ur }}^{\text {ref }}(\mathrm{MPa})$ & Relationship of stiffness parameters \\
\hline $\mathrm{T} 1$ & 2.26 & 1.99 & 1.71 & 11.76 & $\begin{array}{c}E_{\text {oed }}^{\text {ref }}=0.88 E_{s 1-2} E_{50}^{r e f}=0.76 E_{s 1-2} \\
E_{\text {ur }}^{\text {ref }}=5.20 E_{s 1-2}\end{array}$ \\
\hline $\mathrm{T} 2$ & 2.34 & 2.09 & 1.86 & 13.03 & $\begin{array}{c}E_{\text {oed }}^{\mathrm{ref}}=0.89 E_{s 1-2} E_{50}^{\mathrm{ref}}=0.79 E_{s 1-2} \\
E_{\mathrm{ur}}^{\mathrm{ref}}=5.57 E_{s 1-2}\end{array}$ \\
\hline T3 & 2.16 & 2.06 & 2.08 & 15.12 & $\begin{array}{c}E_{\text {oed }}^{\mathrm{ref}}=0.95 E_{s 1-2} E_{50}^{\mathrm{ref}}=0.96 E_{s 1-2} \\
E_{\mathrm{ur}}^{\mathrm{ref}}=7.00 E_{s 1-2}\end{array}$ \\
\hline
\end{tabular}

the relationship between compression modulus $\left(E_{s 1-2}\right)$ and reference secant stiffness $\left(E_{\text {oed }}^{\text {ref }}\right)$ and reference secant stiffness $\left(E_{50}^{\mathrm{ref}}\right)$ and reference unloading/reloading stiffness $\left(E_{\mathrm{ur}}^{\mathrm{ref}}\right)$ of the one-dimensional consolidation tests and triaxial shear tests, it was more convenient to determine the parameters of the HS model [36-39]. The relationship of stiffness parameters of soil samples in Shenzhen Bay in China is shown in Table 5. In recent years, comparisons of parameters of soil and cemented clay of the HS model obtained by researchers are shown in Table 6 [2, 40-46].

From Tables 5 and 6, the stiffness parameters of soft soil and cemented clay of the HS model had the following rules: 
TABLE 6: Comparisons of parameters of soil and cemented clay of the HS model [2, 40-46].

\begin{tabular}{|c|c|c|c|c|c|c|c|c|}
\hline Soil types & $E_{s 1-2}(\mathrm{MPa})$ & $E_{\text {oed }}^{\text {ref }}(\mathrm{MPa})$ & $E_{50}^{\mathrm{ref}}(\mathrm{MPa})$ & $\begin{array}{l}\text { HS model } \\
E_{\mathrm{ur}}^{\mathrm{ref}}(\mathrm{MPa})\end{array}$ & $c^{\prime}(\mathrm{kPa})$ & $\varphi^{\prime}\left({ }^{\circ}\right)$ & $R_{f}$ & Relationship of stiffness parameters \\
\hline Soft soil (Shanghai) & 2.2 & 1.9 & 2.0 & 15.6 & 3.0 & 27.3 & 0.54 & $\begin{array}{c}E_{\text {oed }}^{\text {ref }}=0.9 E_{s 1-2} E_{50}^{\text {ref }}=0.9 E_{\text {oed }}^{\text {ref }} \\
E_{\text {ur }}^{\text {ref }}=7.8 E_{50}^{\text {ref }}=8.2 E_{\text {oed }}^{\text {ref }}\end{array}$ \\
\hline Gault clay & & 4.3 & 14.8 & 44.5 & 0.05 & 33.0 & 0.96 & $\begin{array}{c}E_{50}^{\mathrm{ref}}=3.5 E_{\mathrm{oed}}^{\mathrm{ref}} \\
E_{\mathrm{ur}}^{\mathrm{ref}}=3 E_{50}^{\mathrm{ref}}=10.4 E_{\mathrm{oed}}^{\mathrm{ref}}\end{array}$ \\
\hline Silty clay (Taipei) & & 2.4 & 6.6 & 19.7 & 0.05 & 29.0 & 0.95 & $\begin{array}{c}E_{50}^{\mathrm{ref}}=2.8 E_{\text {oed }}^{\mathrm{ref}} \\
E_{\mathrm{ur}}^{\mathrm{ref}}=3 E_{50}^{\mathrm{ref}}=8.3 E_{\mathrm{oed}}^{\mathrm{ref}}\end{array}$ \\
\hline Clay (Blodgett) & & 1.6 & 2.4 & 10.0 & 0.05 & 24.1 & 0.70 & $\begin{array}{c}E_{50}^{\mathrm{ref}}=1.5 E_{\text {oed }}^{\mathrm{ref}} \\
E_{\mathrm{ur}}^{\mathrm{ref}}=4.3 E_{50}^{\mathrm{ref}}=6.25 E_{\text {oed }}^{\mathrm{ref}}\end{array}$ \\
\hline Lacustrine clay & & 37.6 & 37.6 & 150.4 & 30 & 26 & & $\begin{array}{c}E_{50}^{\mathrm{ref}}=E_{\text {oed }}^{\mathrm{ref}} \\
E_{\text {ur }}^{\mathrm{ref}}=4 E_{50}^{\mathrm{ref}}=4 E_{\mathrm{oed}}^{\mathrm{ref}}\end{array}$ \\
\hline Soft soil (Tianjin) & & 3.4 & 4.4 & 14.0 & 10 & 25.2 & & $E_{50}^{\mathrm{ref}}=(0.5 \sim 1.8) E_{\text {oed }}^{\mathrm{ref}}$ \\
\hline
\end{tabular}

$E_{\text {oed }}^{\text {ref }}, E_{50}^{\text {ref }}$, and $E_{\text {ur }}^{\text {ref }}$ were under reference stress $p^{\text {ref }}=100 \mathrm{kPa}$.

$E_{\text {oed }}^{\mathrm{ref}} \approx 0.9 E_{s 1-2}, E_{50}^{\mathrm{ref}}=(0.7 \sim 1.0) E_{s 1-2}$, and $E_{\mathrm{ur}}^{\mathrm{ref}}=(3 \sim 8)$ $E_{50}^{\text {ref }}=(4 \sim 11) E_{\text {oed }}^{\text {ref }}$, and stiffness parameters in different regions had big differences, so it was better to select parameters of the HS model in the numerical simulation based on field sampling and indoor tests; the relationship of stiffness parameters of soil samples of the HS model in Shenzhen Bay was similar to those obtained in similar studies in Shanghai, Blodgett, and Tianjin, and the value was smaller than that of gault clay and lacustrine clay.

\section{Conclusion}

Based on one-dimensional consolidation tests and triaxial shear tests, the parameters $c^{\prime}, \varphi^{\prime}, E_{\text {oed }}^{\mathrm{ref}}, E_{50}^{\mathrm{ref}}, E_{\mathrm{ur}}^{\mathrm{ref}}$, and $R_{f}$ of the HS model of soft soil in Shenzhen Bay in China were determined, which could provide a reference for the numerical analysis of similar foundation pits. The main findings were as follows:

(1) Based on results of CD tests at the same shear rate, $E_{50}^{\text {ref }}$ and $R_{f}$ were discrete by using $1 / \varepsilon_{1} \sim 1 / q$ curves and $\varepsilon_{1} \sim \varepsilon_{1} / q$ curves, while $\varepsilon_{1} \sim q$ curves had smaller error and better stability. It was more suitable for parameter analysis of the HS model $E_{50}^{\text {ref }}$ and $R_{f}$.

(2) Within a certain range of shear rates in CU tests $(\leq 0.15 \mathrm{~mm} / \mathrm{min})$, with increase of shear rates, shear strength failure value $\left(q_{f}\right)$ and reference secant modulus $\left(E_{50}^{\text {ref }}\right)$ increased gradually, while the failure ratio $\left(R_{f}\right)$ changed little with shear rates, which was close to 1 .

(3) The stiffness parameter ratio $\left(E_{\text {oed }}^{\mathrm{ref}} / E_{s, 1-2}\right)$ of soft soil in Shenzhen Bay was 0.92; the average $\left(E_{50}^{\mathrm{ref}} / E_{s, 1-2}\right)$ was 0.86 ; and the average $\left(E_{\mathrm{ur}}^{\mathrm{ref}} / E_{s, 1-2}\right)$ was 5.92 . Based on $E_{s, 1-2}$ obtained from one-dimensional consolidation tests, the parameters $E_{\mathrm{oed}}^{\mathrm{ref}}, E_{50}^{\mathrm{ref}}$, and $E_{\mathrm{ur}}^{\mathrm{ref}}$ could be obtained quickly.

\section{Data Availability}

The data used to support the findings of this study are available from the corresponding author upon request.

\section{Conflicts of Interest}

The authors declare that they have no conflicts of interest.

\section{Acknowledgments}

This work was supported by the National Natural Science Foundation of China (Grant no. 51678363), Shenzhen Science and Technology project (no. JCYJ20150525092941052), and Underground Engineering (Tongji University) (no. KLETJGE-B0905).

\section{References}

[1] Y. M. W. Zhou, J. Lin, and Y. K. Chen, "Creep behaviors and constitutive model for high density polyethylene geogrid and its application to reinforced soil retaining wall on soft soil foundation," Construction and Building Materials, vol. 114, pp. 763-771, 2016

[2] W. D. Wang, H. R. Wang, and Z. H. Xu, "Experimental study of parameters of hardening soil model for numerical analysis of excavations of foundation pits," Rock and Soil Mechanics, vol. 33, no. 8, pp. 2283-2290, 2012, in Chinese.

[3] L. X. Wang, S. S. Xu, J. L. Qiu et al., "Automatic monitoring system in underground engineering construction: review and prospect," Advances in Civil Engineering, Article ID 3697253, 2020.

[4] T. Liu, Y. J. Zhong, Z. L. Han, and W. Xu, "Deformation characteristics and countermeasures for a tunnel in difficult geological environment in NW China," Advances in Civil Engineering, vol. 2020, Article ID 1694821, 16 pages, 2020.

[5] L. X. Wang, C. H. Li, J. L. Qiu, K. Wang, and T. Liu, "Treatment and effect of loess metro tunnel under surrounding pressure and water immersion environment," Geofluids, vol. 2020, Article ID 7868157, 15 pages, 2020.

[6] L. X. Wang, E. L. Ma, J. X. Lai, S. S. Xu, K. Wang, and T. Liu, "Tunnelling induced settlement and treament techniques for a loess metro in Xi'an," Advances in Civil Engineering, vol. 2020, Article ID 2458615, 16 pages, 2020.

[7] V. Vukadin and V. Jovičić, "S_BRICK: a constitutive model for soils and soft rocks," Acta Geotechnica Slovenica, vol. 15, no. 2, pp. 16-37, 2018. 
[8] J. H. Atkinson and P. L. Bransby, The Mechanics of Soils: An Introduction to Critical State Soil Mechanics, McGraw-Hill, New York, NY USA, 1978.

[9] L. Nguyen and B. Fatahi, "Behaviour of clay treated with cement \& fibre while capturing cementation degradation and fibre failure-C3F model," International Journal of Plasticity, vol. 81, pp. 168-195, 2016.

[10] Y. Aung, H. Khabbaz, and B. Fatahi, "Mixed hardening hyperviscoplasticity model for soils incorporating non-linear creep rate-H-creep model," International Journal of Plasticity, vol. 120, pp. 88-114, 2019.

[11] Y. H. Han, H. Y. Wen, and Q. F. Wei, "Research on the Influence of New Shield Tunnel to Adjacent Existing Tunnel," Applied Mechanics \&Materials, vol. 295-298, pp. 2985-2989, 2013.

[12] C. Y. Ou, P.-G. Hsieh, and D.-C Chiou, "Characteristics of ground surface settlement during excavation," Canadian Geotechnical Journal, vol. 30, no. 5, pp. 758-767, 1993.

[13] K. Ishihara, "Relations between process of cutting and uniqueness of solutions," Soils and Foundations, vol. 10, no. 3, pp. 50-65, 1970.

[14] M. Rouainia and D. Muir wood, "A kinematic hardening constitutive model for natural clays with loss of structure," Géotechnique, vol. 50, no. 2, pp. 153-164, 2000.

[15] X. Liu, E. Liu, and Q. Yu, "A new double hardening constitutive model for frozen mixed soils," European Journal of Environmental and Civil Engineering, vol. 23, pp. 1-21, 2019.

[16] C. Surarak, S. Likitlersuang, D. Wanatowski, A. Balasubramaniam, E. Oh, and H. Guan, "Stiffness and strength parameters for hardening soil model of soft and stiff Bangkok clays," Soils and Foundations, vol. 52, no. 4, pp. 682-697, 2012.

[17] H. F. Schweiger, "Influence of constitutive model and EC7 design approach in FEM analysis of deep excavations," in Proceeding of ISSMGE International Seminaron Deep Excavations and Retaining Structures, pp. 99-114, Budapest, Hungary, 2009.

[18] C. Liu, L. Xing, H. W. Liu et al., "Numerical study of bond slip between section steel and recycled aggregate concrete with full replacement ratio," Applied Sciences, vol. 10, no. 3, Article ID $887,2020$.

[19] M. Calvello and R. J. Finno, "Selecting parameters to optimize in model calibration by inverse analysis," Computers and Geotechnics, vol. 31, no. 5, pp. 411-425, 2004.

[20] B. Simpson, "Retaining Structures: displacement and design," Géotechnique, vol. 42, no. 4, pp. 541-576, 1992.

[21] D. M. Wood, "Kinematic hardening model for structure soil," in Proceedings of the International Conference on Numerical Models in Geomechanics NUMOG5, Pande and Pietruszczak, Eds., pp. 83-88, Davos, Switzerland, 1995.

[22] T. Schanz, P. A. Vermeer, and P. G. Bonnier, "The Hardening Soil Model: Formulation and Verification," Beyond 2000 in Computational Geotechnics, CRC Press, Boca Raton, FL, USA, 1999.

[23] H. F. Schweiger, "Some remarks on pore pressure parameter $\mathrm{A}$ and $\mathrm{B}$ in undrained analyses with the Hardening Soil Model," PLAXIS Bulletin, vol. 12, pp. 6-9, 2002.

[24] A. Al-Tabbaa and D. M. Wood, "An experimentally based "bubble" model for clay," in Proceedings of the International Conference on Numerical Models in Geomechanics, NUMOG 3, P. Pande, Ed., pp. 91-99pp. 91-, Niagara Falls, Canada, May 1989.

[25] A. S. Balasubramaniam and W. Waheed-Uddin, "Deformation characteristics of weathered Bangkok Clay in triaxial extension," Géotechnique, vol. 27, no. 1, pp. 75-92, 1977.
[26] Y. Yuan, R. Liu, C. L. Qiu, and R. J. Tan, "Establishment and application of creep constitutive model related to stress level of soft soil," Journal of Tianjin University (Science and Technology), vol. 51, no. 7, pp. 711-719, 2018, in Chinese.

[27] T. Schanz and P. A. Vermeer, On the Stiffness of Sands. Prefailure Deformation Behaviour of Geomaterials, ICE, London, UK, 1998.

[28] P. A. Vermeer, "A double hardening model for sand," Géotechnique, vol. 28, no. 4, pp. 413-433, 1978.

[29] R. B. J. Brinkgreve, A. I. Khoury, and J. M. Van Esch, Plaxis Version 8: Material Models Manual, A.A. Balkema Publishers, Rotterdam, Netherlands, 2006.

[30] Y. Wang, S. H. Zhang, D. T. Niu, L. Su, and D. M. Luo, "Strength and chloride ion distribution brought by aggregate of basalt fiber reinforced coral aggregate concrete," Construction and Building Materials, vol. 234, Article ID 117390, 2020, In press.

[31] X. Liu, Q. Fang, D. L. Zhang, and Y. Liu, "Energy-based prediction of volume loss ratio and plastic zone dimension of shallow tunnelling," Computers and Geotechnics, vol. 118, Article ID 103343, 2020.

[32] Y. Y. Li, Y. M. Sun, J. L. Qiu, T. Liu, L. Yang, and H. D. She, "Moisture absorption characteristics and thermal insulation performance of thermal insulation materials for cold region tunnels," Construction and Building Materials, vol. 237, Article ID 117765, pp. 1-13, 2020.

[33] Y. Wei, W. Guo, and Q. Zhang, "A model for predicting evaporation from fresh concrete surface during the plastic stage," Drying Technology, vol. 37, pp. 1-11, 2019.

[34] Test methods of soils for highway engineering (JTG E402007), China, 2007, in Chinese.

[35] R. L. Kondner, "Hyperbolic stress-strain response: Cohesive Soils," Journal of the Soil Mechanics and Foundations Division, vol. 89, no. 1, pp. 115-143, 1963.

[36] X. Yue, Y. Xie, H. Zhang, Y. Niu, S. Zhang, and J. Li, "Study on geotechnical characteristics of marine soil at Hong KongZhuhai-Macao tunnel," Marine Georesources \& Geotechnology, vol. 37, no. 8, pp. 1-12, 2019.

[37] T. Liu, Y. J. Zhong, Z. H. Feng, W. Xu, and F. T. Song, "New construction technology of a shallow tunnel in boulder-cobble mixed grounds," Advances in Civil Engineering, vol. 2020, Article ID 5686042, 14 pages, 2020.

[38] D. T. Niu, L. Zhang, F. Qiang, B. Wen, and D. M. Luo, "Critical conditions and life prediction of reinforcement corrosion in coral aggregate concrete," Construction and Building Materials, vol. 238, Article ID 117685, 2020.

[39] S. B. Zhang, S. Y. He, J. L. Qiu, W. Xu, R. Garnes, and L. X. Wang, "Displacement characteristics of a urban tunnel in silty soil by shallow tunnelling method," Advances in Civil Engineering, vol. 2020, Article ID 3975745, 15 pages, 2020.

[40] X. L. Wang, J. X. Lai, J. L. Qiu, W. Xu, L. X. Wang, and Y. B. Luo, "Geohazards, reflection and challenges in mountain tunnel construction of China: a data collection from 2002 to 2018," Geomatics, Natural Hazards and Risk, vol. 11, no. 1, pp. 667-675, 2020.

[41] R. Lüftenegger, H. F. Schweiger, and F. Scharinger, "3D finite element analysis of a deep excavation and comparison with in situ measurements," Geotechnical Aspects of Underground Construction in Soft Ground, pp. 193-199, Taylor \& Francis Group, London, UK, 2009.

[42] Z.J. Zhou, Y.Q. Dong, P.J. Jiang, D.D. Han, and T. Liu, "Calculation of pile side friction by multiparameter statistical analysis," Advances in Civil Engineering, vol. 2019, Article ID 2638520, 12 pages, 2019. 
[43] M. N. Wang, Y. C. Dong, and Y. Li, "Analytical solution for Loess tunnel based on the bilinear strength criterion," Soil Mechanics and Foundation Engineering, vol. 57, no. 3, pp. 151-163, 2020.

[44] J. F. Roboski, Soil Parameters for Constitutive Models of Compressible Chicago Glacial Clays, Northwestern University, Evanston, IL, USA, 2001.

[45] C. W. W. Ng, An Evaluation of Soil-Structure Interaction Associated with a Multi-Propped Excavation, University of Bristol, Bristol, UK, 1992.

[46] C.-Y. Ou, B.-Y. Shiau, and I.-W. Wang, “Three-dimensional deformation behavior of the Taipei National Enterprise Center (TNEC) excavation case history," Canadian Geotechnical Journal, vol. 37, no. 2, pp. 438-448, 2000. 